GA-A- -20765

DE92 006912

\title{
ASSESSMENT OF PERD LOW ACTIVATION MATERIALS
}

\author{
by \\ E.T. CHENG
}

JANUARY 1992

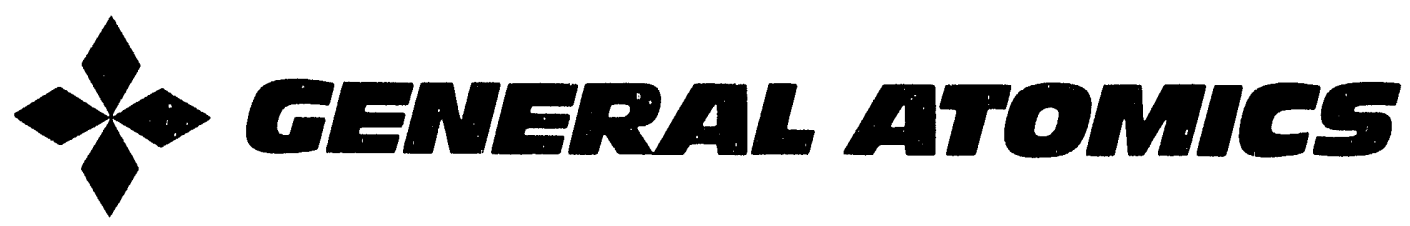




\section{DISCLAIMER}

This report was prepared as an account of work sponsored by an agency of the United States Government. Neither the United States Government nor any agency thereof, nor any of their employees, malces any warranty, express or implied, or assumes any legal liability or responaibility for the accuracy, completeneas, or usefulness of any information, apparatus, product, or process disclosed, or represents that its use would not infringe privately owned rights. Reference herein to any specific commercial product, process, or service by trade name, trademark, manufacturer, or otherwise, does not necessarily constitute or imply its endorsement, recommendation, or favoring by the United States Government or any agency thereof. The views and opinions of authors expreased herein do not necessarily state or reflect those of the United States Government or any agency thereof. 
GA-A20765

\title{
ASSESSMENT OF LOW ACTIVATION MATERIALS
}

\author{
by \\ E.T. CHENG*
}

*TSI Research, Inc.

This is a preprint of a paper to be presented at the 14th Symposium on Fusion Engineering, September 30-October 3, 1991, San Diego, California, and to be printed in the Proceedings.

\author{
Work supported by \\ Department of Energy \\ Contract DE-AC03-89ER52153
}
GENERAL ATOMICS PROJECT 3469
JANUARY 1992

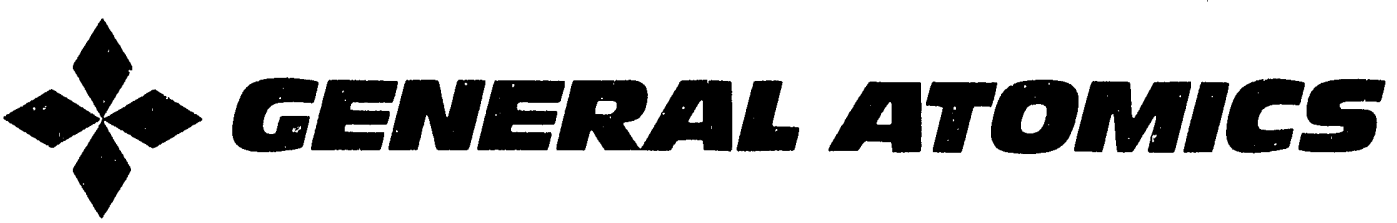

DISTRIBUTION OF TIIIS DOGUMENT IS UNIIMITED

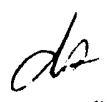




\title{
ASSESSMENT OF LOW ACTIVATION MATERIALS
}

\author{
E.T. Cheng* \\ General Atomics \\ P.0. Box 85608 \\ San Diego, California 92186-9784
}

Abstract: Characteristics of neutron induced radioactivities for low activation materials in a deuterium-tritium fusion power reactor were investigated. The criteria for the assessment of low activation materials were reviewed. Candidate structural materials, namely vanadium alloy ( $\mathrm{V} 5 \mathrm{Cr} 5 \mathrm{Ti}$ ), ferritic steel (modified HT9), and SiC composite material, and tungsten divertor material were considered in the evaluation. The assessment of these candidate materials for fusion reactor applications was made based on the issues of waste disposal, maintenance, afterheat, accidental dose release, and materials recycling. The significance of impurity elements and their levels was addressed using the recently updated activation cross sections.

\section{Introduction}

Fusion power reactors constructed with low activation fusion materials are attractive because of the reduced risks as sociated with the prompt and latent radiation dose to the population due to the release of radioactive inventory during a reactor accident, and waste disposal related environmental issues $[1,2]$. The general considerations for low activation materials are: (1) Low inventory of long-lived radioactive materials to minimize the environmental impacts due to the disposal of do commissioned nuclear components. Reuse of component materials is an option to reduce the quantity of nuclear waste to be disposed of; (2) Reduced shutdown gamma-ray dose rate within and outside the reactor components to allow for both remote and hands-on maintenance; (3) Reduced radioective inventory to minimize the prompt and latent radiation dose released during a reactor accident; and (4) Reduced afterheat to minimize the material temperature rise that could cause the rupture of structural components and the release of radioactive inventory. An initial investigation was done of accident safety, waste management, materiais recycling, effluent, and maintenance considerations for all natural materials [3]. Criteria for low activation materials have recently been discussed [4]. In this paper, the recent development of these low activation criteria was summarized and applied to a candidate furion reactor. An assessment of candidate structural materials based on all aspects of low activation criteria is presented.

\section{Low Activation Criteria and lasues}

\subsection{Waste Disposal}

The criteria for low actination materials in a fusion power reactor were previously discussind [1] and recently reassessed [4]. In Ref. [1], the definition of a low activation material is primarily determined by the abilily to qualify after service in the reactor as a shallow-land burinl radioactive waste. However, shallow-land burial waste disposal, although being emphasized in the United States, is in general not acceptable in Europe and other countries. Recycling of irradiated materials is an attractive alternative being investigated for fusion reactor development.

Shallow land burial waste disposal is regulated by a set of specific activity limits (SAL) for long-lived (half-life longer than 5 years) radionuclides. In the U.S., this set of SALs is given as 10 CFR 61 [5], which is primarily determined for and limited by fission and industrial low-level radioactive wastes.

* Permanent affiliation TSI Research, Inc., Solana Beach, California.
Recently, Fetter, et al., have evaluated the SALs for all radioactive nuclides based on the 10 CFR 61 methodology [6]. For the purpose of our assessment for low activation materials, we have adopted the evaluation of Fetter, et al., of SALs because of its completeness and self-consistency. In principle, the Fetter, etal., and 10 CFR 61 evaluations should provide similar SALs since both were evaluated based on the same methodology and criteria. However, by comparing Fetter, etal., and 10 CFR 61 evaluations, we noted a few discrepancies. These discrepancies occur primarily for the long-lived beta emitters. Table 1 shows some of the triajor discrepancies in SALs: C14, Ni63, and Tc99. The corresponding elemental concentration limits using the 10 CFR 81 and Fetter, et al., evaluations to qualify as shallow-land burial waste will differ accordingly. Table 1 also shows the allowable $\mathrm{N}, \mathrm{Cu}, \mathrm{Ni}$, and $\mathrm{Mo}$ concentrations using these two evaluations for compurison. The reason for the difference between the 10 CFR 61 and Fetter, et al., evaluations of the SALs is mainly becuvere of the reduced intruder dose due to added stability of metal waste in the Fetter, et al., evaluations [6], while the 10 CFR 81 evaluations gave only a factor of 10 reduction for metal woste.

\subsection{Materials Recycling}

Recycle of used materials will help to reduce the quantity of nuclear wante to be disposed of. The European Community countries are particularly interested in this approach $[2,7]$, because these countries have decided that deep geologic disposal of nuclear waste is the only disposal option. The criteria for materials recycling are determined prinarily by the gamma dose rate for remelt and subsequent refabrication of the recycled materials. For hands-on recycling, the limit for the gamma dose rate should be $2.5 \mathrm{mR}$ per hour $(0.025 \mathrm{mSv} / \mathrm{h})$ [4]. The cooling time after decommissioning is assumed to be 100 years or less. However, if the recycling is to be handled remotely, the limit should be $1 \mathrm{R} / \mathrm{h}(10 \mathrm{mSv} / \mathrm{h})$ at 50 years after decommissioning [4]. In the studies performed in Europe, it was revealed that impurity elements, rather than the main alloying elements, are very often the important factors to determine the shutdown gamma dose rate $[4,7]$.

Table 1

Comparison of Specific Activity Limits and Relevent Allowable Elemental Concentrations for Shallow-Land Burial Waste Disposal for $20 \mathrm{MW}-\mathrm{y} / \mathrm{m}^{2}$ Exposure at $5 \mathrm{MW} / \mathrm{m}^{2 *}$

\begin{tabular}{lcr}
\hline \multicolumn{3}{c}{ Specific Activity Limits $\left(\mathrm{Ci} / \mathrm{m}^{3}\right)$} \\
\cline { 3 - 3 } Radionuclide & $\frac{10 \text { CFR 61 }}{80}$ & $\frac{\text { Fettar, et al. }}{6,000.0}$ \\
\hline${ }^{14} \mathrm{C}$ & 7,000 & $7,000,000.0$ \\
${ }^{68} \mathrm{Ni}$ & 30 & 0.6
\end{tabular}

Allowable Elemental Concentration

\begin{tabular}{|c|c|c|}
\hline Element ${ }^{\dagger}$ & 10 CFR 61 & Fetter, et al. \\
\hline $\begin{array}{cc}\mathrm{N} & \left({ }^{14} \mathrm{C}\right) \\
\mathrm{Cu} & \left({ }^{08} \mathrm{Ni}\right) \\
\mathrm{Ni} & \left({ }^{68} \mathrm{Ni}\right) \\
\text { Mo } & \left({ }^{00} \mathrm{Tc}\right)\end{array}$ & $\begin{array}{l}987 \mathrm{ppm} \\
0.14 \% \\
0.48 \% \\
100 \mathrm{ppm}\end{array}$ & $\begin{array}{l}7.4 \% \\
\text { No limit } \\
34 \% \\
2 \mathrm{ppm}\end{array}$ \\
\hline
\end{tabular}

"From 10 CFR 61 and Fetter, et al., evaluations.

tContributing long-lived radionuclide. 


\subsection{Maintenance}

Maintenance is an important consideration in the operation of a fusion power reactor. To access and service a reactor component, the limitation is again the gamma dose rate. The criteria on the gamma dose rates for hands-on and remote maintenance are similar to that for materials recycling: $2.5 \mathrm{mk} / \mathrm{h}$ $(0.025 \mathrm{mSv} / \mathrm{h})$ for hands-on and $1 \mathrm{R} / \mathrm{h}(10 \mathrm{mSv} / \mathrm{h})$ for remote maintenance, respectively [4]. The time scale, however, must be days after shutdown rather than decades. Remote maintenance in a radiation field higher than $1 \mathrm{R} / \mathrm{h}(10 \mathrm{mSv} / \mathrm{h})$ gamma dose rate is also possible and should be considered, particularly for the component such as the plasma chamber. However, there are radiation-related limits for the components of remote maintenance equipment such as optical and electronics elements. Two radiation limits were established for these radiation-sensitive components: $1 \times 10^{6} \mathrm{rads} / \mathrm{h}\left(1 \times 10^{4} \mathrm{~Gy} / \mathrm{h}\right)$ for the gamma dose due to radiation ionization-induced interferences; and $1 \times 10^{\circ} \mathrm{rads}\left(1 \times 10^{7} \mathrm{~Gy}\right)$ for the accumulated gamma dose due to radiation damage considerations.

\subsection{Afterheat and Radionctive Inventory}

Afterheat is one of the important energy sources to beat and melt the structural components in a fusion power reactor, causing the release of radioactive inventory in a credible accident. The radioactive inventory and specific radioisotopes are important to determine the radiation dose, prompt or latent, imposed on the general public during and after a reactor accident. In general, proper safety engineering designs and concepts will help to prevent the releace of radioactive inventory from a reactor accident. However, intrinsic safety where the afterheat and radioactive inventory are small enough to uvoid a basardous level of release of radioactivity is the ultimate potential for fusion to achieve. This is normally not the case for a fusion reactor with metallically structured components [3]. A general rule in this area is thus to have the goal of "as low as possiblen afierheat and radioactive inventory.

\section{Candidate Low Activation Materials}

Candidate low activation structural and tritium breeding materials are determined primarily based on the choice of alloy. ing and compounding elements to avoid the production of large quantity of long-lived radionuclides. For the structural materiais, the focus of development is centered on the following materials [4]: (1) Reduced activation martensitic or ferritic steels. The development of this type of alloy involves the removal of $\mathrm{Mo}$ as an alloying element and $\mathrm{Nb}$ as an impurity element from the conventional martensitic or ferritic steels. To retain the necessary alloy properties, W, V, or Ta have been considered as substitutes for Mo. However, high afterheat and prompt dose due to $W$ and $T a$ have to be accounted for in the modified steels. Isotopic tailoring for the $W$ element may be a solution, although it may result in some cost penalty [8]; (2) Vanadium alloy. This type of alloy includes mainly V-Cr-Ti and V-Ti-Si alloys, with $\mathrm{V}-\mathrm{Cr}-\mathrm{Ti}$ a more promising candidate alloy $[4]$; and (3) Ceramics. The main candidate materials in this area are $\mathrm{SiC}$ and $\mathrm{C}$ composites. The metal-matrix ceramic composites such as SiCAl should not be emphasized because of their high activation and relatively low operating temperatures that are not consistent with the generally very low activation features of SiC and C. The critical issues and development needs for all the above candidate low activation materials were outlined in Ref. [4].

Candidate low activation breeding materials are mainly: (1) Solid breeders. This type of materials includes lithium bearing oxides and silicates such as $\mathrm{Li}_{2} \mathrm{O}$ and $\mathrm{Li}_{4} \mathrm{SiO}_{4} ;$ and (2) Liquid breeders. Liquid lithium, FLiBe molten salt, and $\mathrm{Pb}$-Li alloy are among the main candidate materials in this area. Lead-lithium eutectic could be a potential liquid metal other than lithium to be employed as a coolant for a self-cooled blanket concept if the bismuth content in lead due to both impurity and neutron transmutation can be controlled. By removing the excess bismuth content, the corresponding ${ }^{210} \mathrm{Po}$ hazard level will be drastically reduced. A significant decrease in the maximum local afterheat from induced radioactivity in lead is also possible because of the effect of mixing and diluting of the irradiated $\mathrm{Pb}-\mathrm{Li}$ in the self-cooled blanket concept.

In the following analysis and assessment, the focus was placed on the subject of structural materials. Specifically, ferritic steel HT9 (Fe-12Cr), Vanadium alloy (V-5Cr-5Ti), and SiC were investigated in detail. Tungsten was also examined because of its potential use as a plasma-facing material of the divertor component.

\section{Methads of Analysis}

Neutron spectra were calculated using the methods described in Ref. [3] using the ENDF/B-V based nuclear data library and REAC activation calculation code and library system [9]. Note that newly measured and evaluated cross sections leading to the production of long-lived radionuclides were also included in the analysis to either supplement or update the REAC2 activation cross section library [10]. The blanket model used for producing the neutron spectra needed for the analysis is similar to the liquid lithium self-cooled blanket with vanadium alloy structure evaluated in the Blanket Comparison and Selection Study (BCSS) [11]. The blanket model consists of a $3 \mathrm{~mm}$ first wall ( $100 \%$ vanadium alloy), a $0.5 \mathrm{~m}$ breeding zone $(7.1 \%$ vanadium alloy $+73.7 \%$ liquid lithium), and a $0.5 \mathrm{~m}$ reflector ( $10 \%$ vanadium alloy $+10 \%$ liquid lithium $+80 \%$ vanadium $)$. A neutron wall loading of $5 \mathrm{MW} / \mathrm{m}^{2}$ was assumed for all activation calculations. The operating time was assumed to be 4 years continuoualy, resulting in a total exposure of $20 \mathrm{MW}-\mathrm{y} / \mathrm{m}^{2}$ at the first wall component.

\section{Ascesement and Discussion}

In the following, assessments and discussions were given for the candidate structural and divertor materials considering low activation criteria deacribed in Section 2.

\subsection{Weste Disposed}

Assessment was made for shallow-land burial (Class C) waste disposal of the candidate structural and tungsten divertor materials. Table 2 shows the waste disposal rating for the candidate structural materials after $20 \mathrm{MW}-\mathrm{y} / \mathrm{m}^{2}$ neutron exposure. Table 3 gives the allowable concentrations for all natural elements in the first wall and blanket components of the $\mathrm{V} / \mathrm{Li}$ fusion blanket to qualify for shnllow-land burial waste disposal. The allowable concentration limits for the minor alloying elements and impurities can thus be obtained from Table 3 . The criteria assumed are the specific activity limits for long-lived radionuclides evaluated by Fetter, et al, as described in Section 2. The conclusions are: (1) The vanadium alloy and ferritic steel main alloying elements qualify as shallow-land burial waste, as shown in Table 2; (2) SiC furst wall component alone may not qualify as shallow-land burial waste, as shown in Table 2 . However, the blanket component made out of $\mathrm{SiC}$ is a shallow-land

Table 2

Waste Disposal Ratings for Shallow-Land Burial Disposal (Exposure: $20 \mathrm{MW}-\mathrm{y} / \mathrm{m}^{2}$ )

\begin{tabular}{lccc}
\hline \multicolumn{4}{l}{ Clase C Waste Disposal Ratings } \\
\hline & SiC & VCrTi & FeCr \\
\hline $\begin{array}{l}\text { First Wall } \\
\text { Only }\end{array}$ & 1.0 & (No limit) & (No limit) \\
$\begin{array}{l}\text { Blanket } \\
\text { Average }\end{array}$ & $<0.05$ & (No limit) & (No limit) \\
\hline
\end{tabular}

-Exclude other minor alloying elements and impurities. 
Table 3

Concentration Limits and Major Contributing Radionuclides in the First Wall and Blanket Components of a Lithium Self-Cooled Vanadium Alloy Fusion Blanket for Shallow-Land Burial Waste Dispoeal ${ }^{\bullet}$ After $20 \mathrm{MW}-\mathrm{y} / \mathrm{m}^{2}$ Expoeure

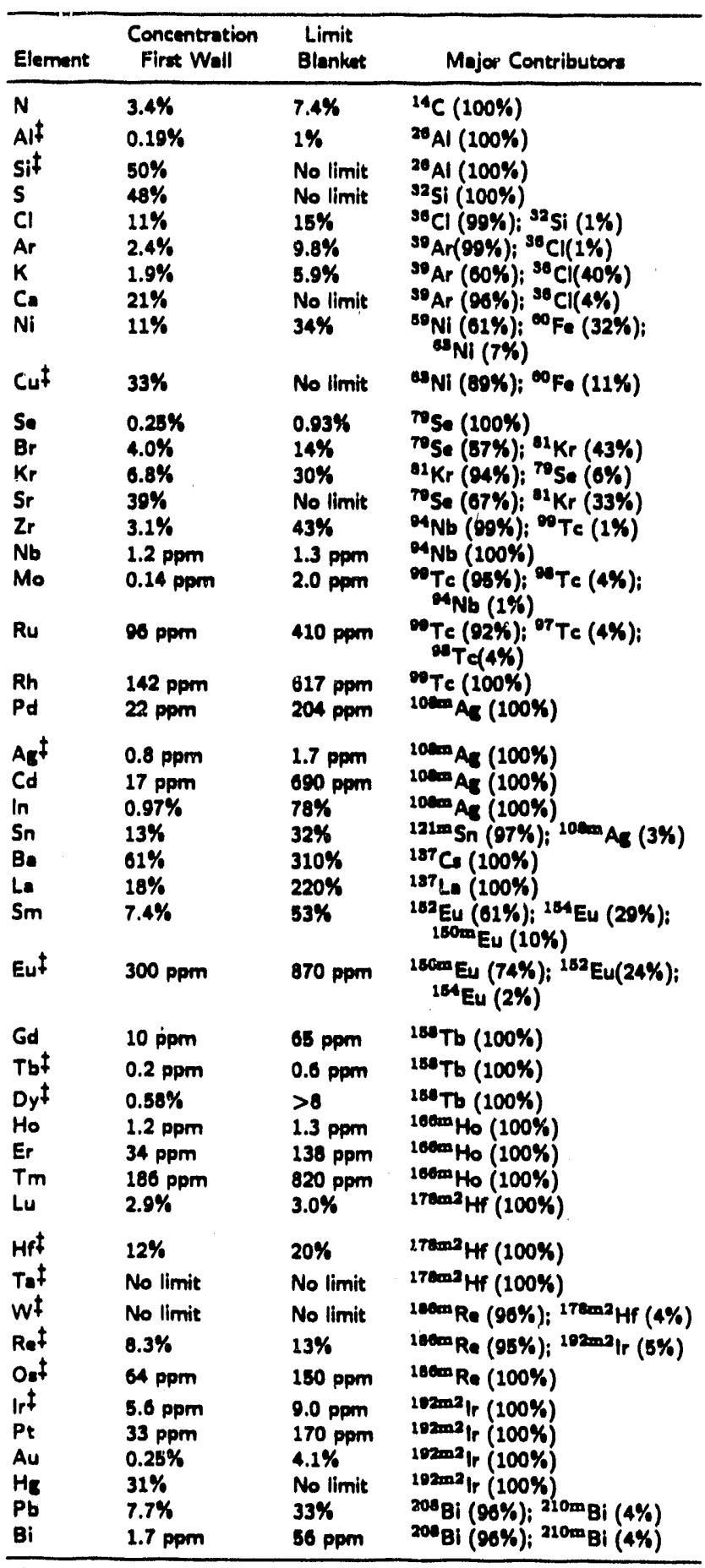

Specific activity limita for shallow-land burial mate dispoeal evaluated by S. Fetter, et al., Ine Fusion Ens. Deaion 13 (1990) 239/ mare adopted.

tBand on REAC2 Calculations and Revisions.

†New measurements and educated extimates are considereyd.

Notea:

Elements having no concentration limits in first wall and tylanket materials we those not listed above $(Z<84)$. Theas include the following 36 elements: $H, H e, L i, B e, B, C, O, F$, Ne, Ne, Mc, P, Sc, Ti, V, Cr, Mn,
Fe, Co, Zn, Ga, Ge, As, Rb, Y, Sb, Te, I, Xe, Cs, Ce, Pr, Nd, Ta, W, and $\mathrm{TI}$.

- Tantalum and tungaten are no longer limited due to recent crose esction measurements and brenchinc ratio estimates.

- Hafnium is allowed for more than $10 \%$ (per $20 \mathrm{MW}-\mathrm{y} / \mathrm{m}^{2}$ ) in the firct wall, siso due to recent meacured data.

burial waste when blanket averaging over the structural material is allowed. This is also shown in Table 2; (3) Tungsten as a divertor material is also a shallow-land burial waste, as shown in Table 3; and (4) Concentration limits for important impurity elements are restricted as shown brilow.

\begin{tabular}{lll}
\hline $\begin{array}{c}\text { Concentration } \\
\text { Limit }\end{array}$ & $\begin{array}{c}\text { First Wall } \\
\text { Component }\end{array}$ & $\begin{array}{c}\text { Blanket } \\
\text { Component } \\
\text { (Averaging) }\end{array}$ \\
\hline$<1$ ppm & $\mathrm{Ag}, \mathrm{Mo}, \mathrm{Tb}$ & $\mathrm{Tb}$ \\
$<10$ ppm & $\mathrm{Bi}, \mathrm{Gd}, \mathrm{Ho}$, & $\mathrm{Ag}, \mathrm{Ho}, \mathrm{Ir}, \mathrm{Mo}$, \\
& $\mathrm{Nb}, \mathrm{Ir}$ & $\mathrm{Nb}$ \\
$<100$ ppm & $\mathrm{Cd}, \mathrm{Er}, \mathrm{Os}$, & $\mathrm{Bi}, \mathrm{Gd}$ \\
& $\mathrm{Pd}, \mathrm{Pt}, \mathrm{Ru}$ & \\
\hline
\end{tabular}

\subsection{Afterheat}

The afterheat values were estimated and analyzed for the candidate materials. A figure of merit to compare the significance of the afterheat values is the adiabatic temperature rise in the material component due to afterheat heating. Note that a credible engineering design will be needed to remove the accumulated decay energy. The adiabatic temperature rise is just an index to indicate the worst case temperature the decay energy would cause in the case of an extremely exaggerated reactor accident. Table 4 shows the adiabatic temperature rises in the candidate materials at $1 \mathrm{~h}$ and 1 day after loss of the coolant. Also shown in Table 4, are the melting temperatures and

operating temperatures of the candidate materials.

Adiabatic heating times to reach the melting temperatures for the candidate structural materials are tabulated in Table 5. Note that as shown in Table 5, the adjabatic afterheat heating

Table 4

Melting Temperatures, Operating Tomperatures, and Adiabatic Temperature Responses Due to Afterheat Energy ( $5 \mathrm{MW} / \mathrm{m}^{2}$ Neutron Wall Losding)

\begin{tabular}{|c|c|c|c|c|}
\hline Material & $\underset{\text { V-Alloy }}{\text { V-i5Cr-5Ti) }}$ & $\begin{array}{l}\text { tructural Material } \\
\text { Ferritic Steel } \\
(\text { Fe-12 Cr) }\end{array}$ & $\begin{array}{l}\text { Diverter } \\
\text { SiC }\end{array}$ & $w$ \\
\hline $\begin{array}{l}\text { Melting } \\
\text { Temperature } \\
\left({ }^{\circ} \mathrm{C}\right)\end{array}$ & 1,890 & 1,420 & $\begin{array}{l}2,700 \\
\text { ecomposes) }\end{array}$ & 3,410 \\
\hline $\begin{array}{l}\text { Maximum } \\
\text { Operating } \\
\text { Temperature } \\
\left({ }^{\circ} \mathrm{C}\right)\end{array}$ & 700 & 550 & 1,000 & 1,000 \\
\hline \multicolumn{5}{|c|}{ Adiabatic Heating Temperatures due to Induced Afterheat } \\
\hline \multicolumn{5}{|l|}{$\begin{array}{l}\text { Time After } \\
\text { Shutdown }\end{array}$} \\
\hline $1 \mathrm{~h}$ & 1,145 & $\begin{array}{l}1,920 \\
\text { (Melt) }\end{array}$ & 1,500 & 3,200 \\
\hline 1 day & $\begin{array}{l}8,640 \\
\text { (Melt) }\end{array}$ & $\begin{array}{l}9,010 \\
\text { (Melt) }\end{array}$ & 2,600 & $\begin{array}{l}51,000 \\
\text { (Melt) }\end{array}$ \\
\hline
\end{tabular}


Table 5

Adiabatic Heating Time:

to Reach Meiting Temperatures

After Exposure to $5 \mathrm{MW} / \mathrm{m}^{2}$

for $20 \mathrm{MW}-\mathrm{y} / \mathrm{m}^{2}$

\begin{tabular}{l}
\hline SiC -1 dey \\
V5Cr5Ti $-3 h$ \\
Fe12Cr $-0.5 h$ \\
(HT9) \\
W $-1 h$
\end{tabular}

times to reach melting temperatures range from $0.5 \mathrm{~h}$ to 1 day. Ferritic steel exhibit the shortest time, $0.5 \mathrm{~h}$, and is followed by $\mathrm{W}, 1 \mathrm{~h}$, and V5Cr5Ti, $3 \mathrm{~h}$.

\subsection{Maintenance}

Table 6 summarizes the shutdown dose rate in the plasma chamber and the ability for hands-on maintenance behind the blanket at 10 days after shutdown. As shown in Table 6, the gamma dose rates in the plama chamber for all candidate materials are of the orders of $1 \times 10^{6} \mathrm{R} / \mathrm{h}$ or more at $1 \mathrm{~h}$ after shutdown. They will decay as the components cool down at times after shutdown. However, the gamma dose rates for all candidate materialo, except vanadium alloy, remain at a level higher than $1 \mathrm{R} / \mathrm{h}$ at 10 years after shutdown.

The vanadium alloy will allow for hands-on maintenance in the plasms chamber at 10 years after shutdown, since the gamma dose rate at that cooling time will be about $1 \mathrm{mR} / \mathrm{h}$.

At the location behind the blanket, the gamms dose rates will be reduced at least by one to two orders of magnitude. Howover, the reduction is, in general, not sufficient for any candidate materials except $\mathrm{SiC}$, to allow for handm-on maintenance at 10 days after cooling. Hands-on maintenance is possible for the $\mathrm{SiC}$ blanket due the reasons given below. The $\mathrm{SiC}$ gamma dose rate is contributed mainly by ${ }^{31} \mathrm{Si}$ (half-life $2.6 \mathrm{~h}$ ), ${ }^{24} \mathrm{Na}$ $(15 \mathrm{~h}),{ }^{22} \mathrm{Na}(2.2$ years $)$, and ${ }^{28} \mathrm{Al}\left(7.2 \times 10^{8} \mathrm{y}\right)$. The ${ }^{31} \mathrm{Si}$ activity is from the first generation neutron reaction and shows the highest level at shutdown. It decays completely at 10 days after shutdown due to the relatively short half-life. The activities from ${ }^{24} \mathrm{Na},{ }^{22} \mathrm{Na}$, and ${ }^{20} \mathrm{Al}$ are from two-step neutron reactions and are generally second order effects compared to ${ }^{31} \mathrm{Si}$. The ${ }^{24} \mathrm{Na}$ activity will drop significantly at 10 days after shutdown. The levels of gamma dose rates in the plamma chamber for ${ }^{22} \mathrm{Na}$ and ${ }^{20} \mathrm{Al}$ are 10 and $1 \mathrm{R} / \mathrm{h}$, respectively, at shutdown. Although these activities will not decay away in 10 days, their activity levels are drastically reduced at the blanket location near the shield because of the threshold, (n, n'p) reactions.

For remote maintenance in the plasma chamber, a necessary step is to allow the equipment to get into the plasma

Table 6

Shutdown Gamma Dose Rates in the Plasma Chamber and Ability for Hands-on Maintenance Behind the Blanket After $20 \mathrm{MW}-\mathrm{y} / \mathrm{m}^{2}$ Exposure at $5 \mathrm{MW} / \mathrm{m}^{2}$

\begin{tabular}{lllll}
\hline & \multicolumn{4}{c}{ Gammo Dose Rate (rads/h) } \\
\cline { 2 - 5 } $\begin{array}{l}\text { Time After } \\
\text { Shutdown }\end{array}$ & SiC & VCrTi & FeCr & W \\
\hline $1 \mathrm{~h}$ & $10^{\circ}$ & $10^{7}$ & $10^{7}$ & $10^{8}$ \\
3 Weeks & $10^{1}$ & $10^{5}$ & $5 \times 10^{6}$ & $10^{7}$ \\
10 Years & 1 & $10^{-3}$ & $10^{2}$ & $10^{4}$ \\
Hands-On & Yes & No & No & No \\
Behind Blanket? & & & & \\
\hline
\end{tabular}

chamber. There is a limit on gamma dose rate for electronic devices to be accurately operational as described in Section 2. Thus, it is important to estimate the cooling times needed to reduce the shutdown gamma dose rate in the plasma chamber to a level below such limit, $1 \times 10^{\circ} \mathrm{rads} / \mathrm{h}$. Table 7 displays the results of the analysis. It shows that it takes about $1 \mathrm{~h}$ and 4 days, respectively, for the $\mathrm{SiC}$ and vanadium blanket to allow for remote maintenance in the plasma chamber. However, it will require 2 months and 2 years cooling times, respectively, for $W$ and ferritic steel.

\section{5,4. Safety}

As mentioned in Section 2, safety engineering design plays a significant role in determining the acceptability of a fusion power reactor. However, there is always a safety-related figure of merit based on the radioactive inventory issue [4]. To demonstrate this figure of merit, an analysis was performed to eatimate the relative latent dose due to the release of $100 \%$ of the radioactive inventory (same first wall thickness) in fusion blankets structured with the candidate materials considered in this paper. The latent dose is the accumulated dose received by the population within 50 years after the reactor accident. Table 8 shows the results relative to ferritic steel. It clearly indicates, as displayed in Table 8, that $\mathrm{SiC}$ gives the most advantageous latent dose figure of merit. It is followed by the vanadium alloy. Tungsten, however, shows the worst figure of merit among all candidate materials [8]. Note that the assumptions of $100 \%$ release is not realistic in a credible reactor accident. However, it gives a safety comparison for the maximum consequences.

Table 7

Required Cooling Times Before Remote

Maintenance Becomes Possible in the Plasma Chamber

(Criteria: Maximum Gammo Dose Rate: $1 \times 10^{6} \mathrm{rads} / \mathrm{h}$ )

\begin{tabular}{ll}
\hline SiC & $1 \mathrm{~h}$ \\
V5Ti5Cr & 4 days \\
HTg (Fo12Cr) & 2 years \\
W & 2 months \\
\hline
\end{tabular}

\subsection{Materials Recycling}

As far as the materials recycling issue is concerned, more extensive investigations have been performed in Europe [7] than in the U.S. In this paper, only a brief comparison on the major alloying or compounding elements was given for the candidate structural materials. Table 9 shows the concentration limits for the initial stage of recycling of irradiated first wall and blanket materials. As shown in Table 9, all major alloying elements for V5Cr5Ti, SiC, and HT9 (Fe12Cr) first wall components meet the remote recycling criteria, i.e., $1 \mathrm{R} / \mathrm{h}$ gamma dose after 50 years of cooling. Further, V5Cr5Ti and HT9 major alloying elements could also be hands-on re-fabricated $(2.5 \mathrm{mR} / \mathrm{h}$ after 100 years of cooling). For the blanket components, hands-on recycling is possible for all candidate structural materials when impurities are not accounted for. The isoue of impurities will require a more detailed future investigation with specific neutron spectra in the first wall, blanket, and shieid components.

\section{Acknowledgment}

This work was sponsored by the U.S. Department of Energy under Contract No. DE-AC03-89ER52153.

\section{References}

[1] R. Conn, etal., "Lower Activation Materials and Magnetic Fusion. Reactors," Nucl. Technol./Fusion, vol. 5, p. 291 (1984). 
Table 8

Relative Latent Doses Due to $100 \%$

Release of Induced Radionctive Inventories After $20 \mathrm{MW}-\mathrm{y} / \mathrm{m}^{2}$ at $5 \mathrm{MW} / \mathrm{m}^{2}$

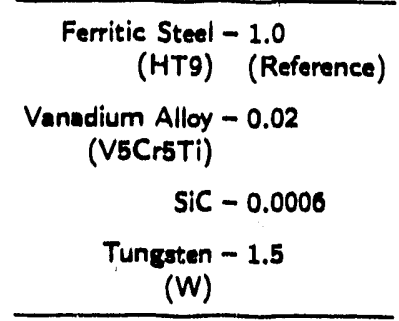

[2] N. O. Jarvis, "Low-Activity Materials: Reuse and Disposal," AERE-R 10860, UKAEA Harwell Report, July 1983.

[3] S. Piet, et al., "Initial Integration of Accident Safety, Waste Management, Recycling, Effluent, and Maintenance Considerations for Low-Activation Materials," Fusion Technol, vol. 19, p. 146 (1991).

[4] D. R. Harries, et al., "Summary," Proc. Workshop on Low Activation Materials, Executive Version, Culham, Great Britain, vol. I, pp. 8-12, April 1991.

(5) Code of Federal Regulations, Licensing Requirements for Land Disposal of Radioactive Waste, Title 10, Pert 61, Washington, D.C., Nuclear Regulatory Commisaion, December 30, 1982.

[6] S. Fetter, E. T. Cheng, F. M. Mann, "Long-term Radioactive Waste from Fusion Reactors: Part II," Fusion Eng. Des., vol. 13 p. 239 (1990).

[7] M. J. Plews, A. R. Davis, G. J. Butterworth, "The CostBenefit of Recycling Low Activity Steels from Fusion Reactors," Culham Laboratory Report CLM-R296, UKAEA, August 1989.
Table 9

Concentration Limits of Candidate Structural Materials" for Matiarials Recycling After $20 \mathrm{MW}-\mathrm{y} / \mathrm{m}^{2}$ Exposure at $5 \mathrm{MW} / \mathrm{m}^{2}$ and 50 Years Decay

\begin{tabular}{|c|c|c|c|}
\hline $\begin{array}{l}\text { Recycling: } \\
\text { Method }\end{array}$ & Firat Wall & ponent & $\mathrm{FeCr}$ \\
\hline $\begin{array}{l}\text { Remote } \\
(1 R / h)\end{array}$ & No limit & No limit & No limit \\
\hline \multirow{2}{*}{$\begin{array}{l}\text { Hands-on } \\
(2.5 \mathrm{mR} / \mathrm{h})\end{array}$} & $0.1 \%$ & No limit & No limit \\
\hline & \multicolumn{3}{|c|}{ Blanket Component } \\
\hline $\begin{array}{l}\text { Remote } \\
(1 \mathrm{R} / \mathrm{h})\end{array}$ & No limit & No limit & No limit \\
\hline $\begin{array}{l}\text { Hende-on } \\
(2.5 \mathrm{mR} / \mathrm{h})\end{array}$ & No limit & No limit & No limit \\
\hline
\end{tabular}

- Major alloying elementes only.

[8] S. Herring, etal, "Activation Product Safety in the ARIES-I Rleactor Design," Fuion Technol., vol. 19 p. 1386 (1991).

[9] F. M. Mann, "REAC2: Status of Codes and Libraries," Furion Tachnol, vol. 15 p. 449 (1989).

[10] Wang DaHai (ed.), Proc. IAEA Consultants' Meeting, (Argonne National I aboratory, September 1989) INDC (NDS)-23:/L, LAEA Nuclear Data Section.

[11] D. L. Smith, etal, "Blanket Comparison and Selection Study, Final Report," Argorine National Laboratory ANL/ FPP-84-1 (1984); see also D. L. Smith, etal., Fusion Technol., vol. 8 p. 10 (1985). 

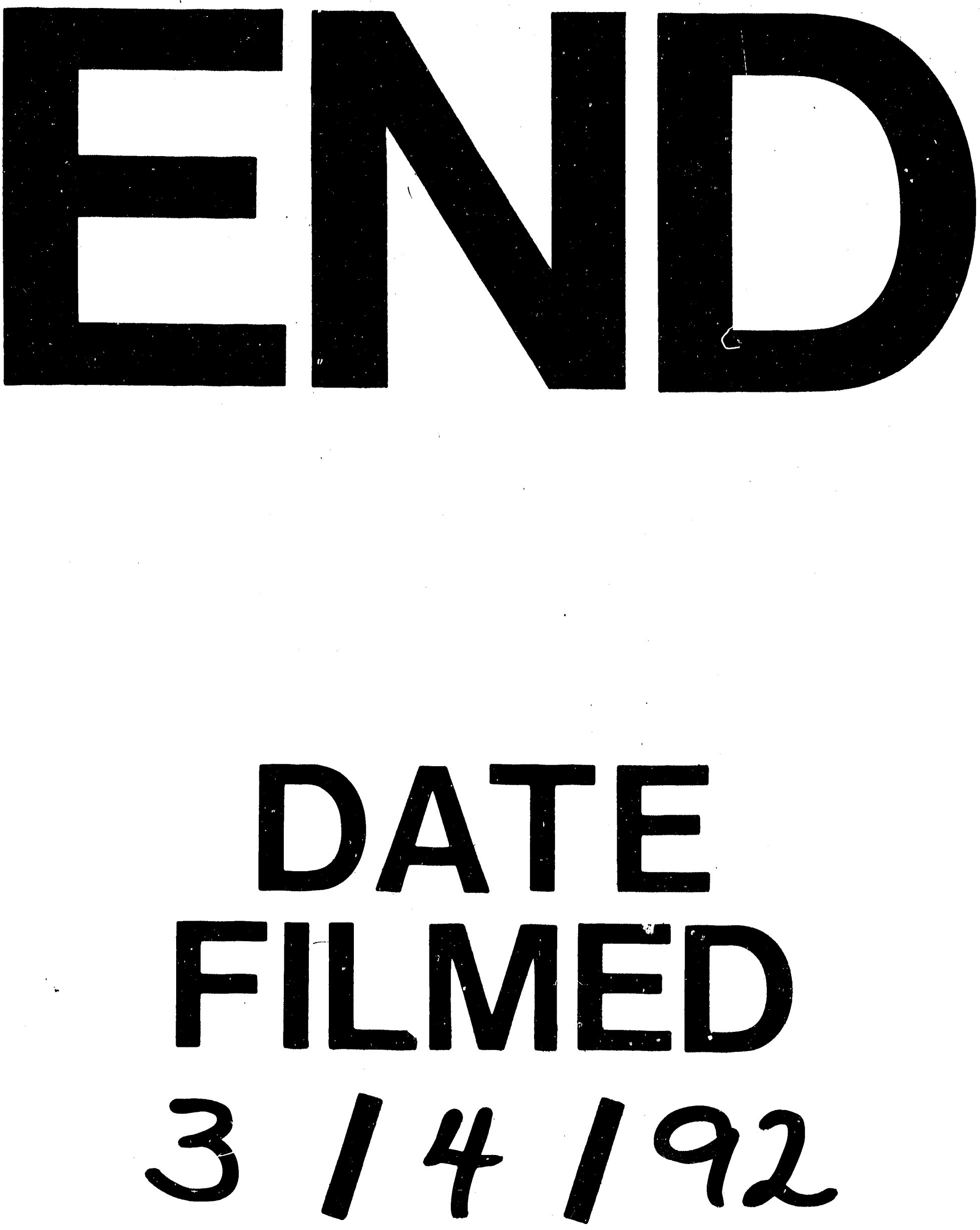

1 
